\title{
Perception of Adult Learners and Challenges of Integrated Functional Adult Literacy Programme Implementation in Shashemene City Administration, Oromia Region
}

\author{
Birhanu Jima \\ Department of Adult Education and Community Development, college of Education and Behavioral Studies. \\ Madda Walabu University Bale Robe Ethiopia \\ Ayele Kumsa \\ Department of Adult Education and Community Development, college of Education and Behavioral Studies. \\ Madda Walabu University Bale Robe Ethiopia
}

\begin{abstract}
The Purpose of this study was to assess the perception of adult learners and Challenges of integrated functional adult literacy programme implementation in Shashemene City Administration. To achieve the purpose; Mixed method of research design was employed; both quantitative and qualitative data were gathered through questionnaire, interviews and focus group discussion. The questionnaires were distributed to 130 respondents. Out of these questionnaires $120(92.3 \%)$ were correctly filled and returned. In addition, twenty four experts were interviewed. Quantitative data were analyzed using descriptive statistics(percentage, frequency, mean and independent t-test). Qualitative data were analyzed using narrative and thematic description. The major findings revealed that since the introduction of adult education programs with an integrated manner the learners positive perception, positive attitudes towards the program, satisfaction of learners with teaching-learning process in the IFAL center, adult learners have understanding on the advantage (importance) of to be literate, their confidence when participating through IFALP and they are direct beneficiaries of IFALP. The major challenges identified, poor integration and coordination among the sectors, lack of financial package, trained personnel and lack of interest and motivation of facilitators, low commitments among political leaders to sustain the IFAL program, lack of connecting the program with primary education program in curricula and low payment of facilitators and coordinators were the major bottlenecks in the practice of IFAL program implementation. Therefore, to alleviate these problems, allocation of necessary budget, encouraging IFAL Stakeholders participation building their capacity, training of facilitators and improving the amount of their payments, developing relevant IFAL curriculum, equipping IFAL centers with the necessary educational materials and facilities, developing commitment leaders to sustain the literacy campaign, developing learners attitudes and interest towards the program were suggested.
\end{abstract}

Keywords: Functionality, Integrated functional adult literacy programme, Adult education, Challenges

DOI: $10.7176 / \mathrm{JEP} / 11-28-04$

Publication date:October $31^{\text {st }} 2020$

\section{Background of the study}

Education is the base for economic, social and political development. It has both individual and social benefits. It helps people to acquire knowledge and skills. In relation to this, the Ethiopian Ministry of Education (2010) stated that education is a key instrument for development. Moreover, every human being has the right to get basic education irrespective of his or her colour, religious background, economic status, ethnic group, etc.

Education is also the major force of change and development and helps people to adjust according to a situation. This benefit of education has become very important today. This is because social changes takes place with increasing speed and affect the lives of more and more people. Education can help people to better understand these changes and provides the skills for adjusting to them (MoE, 2009).

However, formal education alone is not enough to bring rapid and continuous social and economic development. It is not also the only means of satisfying the education needs of people. People who do not get the opportunity of formal education should be provided with other alternative ways. One of these alternative ways is non-formal education. There are three modes through which one can gain knowledge. Concerning to this, Aggarwal (2002) expressed them as: formal, non-formal and informal. In several cases, the non-formal education approach is the complement of formal education. MoE (2010) stated that adult education is an essential process directed arising the knowledge and skills of citizens aged 15 years and above starting from basic reading, writing and computing skills in an organized manner.

Integrated functional adult literacy (IFAL) is one of the ways of literacy programs through which adults' education is directly linked with the livelihood of the society. It is a program designed to help adults to solve their daily life problems. The concept of IFAL is defined in a Master Plan for Adult Education, which the MoE is developing with the support of (DVV) Des DeuschenVolkshochschuulVerbandes (Institute for international 
cooperation of the German Adult Education Association). In general terms it seeks to link writing, reading, numeracy skills to livelihoods and skills training in areas such as agriculture, health, civic, cultural education, etc.

Functional Adult Literacy program enables adult to take informed decisions in daily life of an individual or groups. It also empowers a person or people to participate actively in ones or their affairs. It helps beneficiaries to generate income, fight against poverty, and promote lifelong learning and so on. Concerning this, IIZ/DVV International (2005) stated that the essence and degree of functionality and the need are directly related to the relevant and appropriateness of the program to successfully challenge the various life problems.

The implementation of adult literacy programmes should be based on partnership between various stake holders including the adult learners themselves (MGL\&SD, 2002). Despite that, the adult learners have had very limited influence on provision. The participation should involve active involvement and control in all decisions related to objectives and activities as well as the implementation of the activities (Kagoda, 1999) as opposed to the participation that merely allows them a limited role in just a few activities determined by the programme managers. Adult learners who participate in adult literacy programmes may have positive or negative attitudes. A study of adult learners' perceptions done in Mozambique (Linden \& Rungo 2004) found out that some of these learners may perceive that literacy is useful and the following answers were given by the participants: 'surviving', 'developing one's full capacities', 'living and working in dignity', 'participating fully in development' and 'improving the quality of life', (p. 193).

On the other hand, participants may have negative perception because of the way the programmes are organized. Makgwana Rampedi (2004) found out that in South Africa, some participants in the Ikwelo project had negative attitudes towards literacy projects because the projects were designed with very little or no participation of the communities in which they were to be implemented. This may result in the projects not meeting the learners' needs especially the need to get out of poverty.

The study conducted by Adewale (2003) in Nigeria described that, the major challenges facing adult education delivery in Nigeria are accessibility, inadequate funding, lack of community mobilization, inadequate number of qualified facilitators and poor attitude of the target group. In the case of Ethiopia, adult education is engaged with problems such as an unavailability of appropriate organizational structure to lead adult education, unsatisfactory expansion of adult education, low participation in adult education and low level of relevance of quality of adult education (MoE, 2008).

Although adult education in Ethiopia was started in the past and practiced for long period of time and still practicing, yet it has not achieved the desired level (MoE, 2010). Shashemene City Administration has eight SubCities. Currently, six hundred thrifty four IFAE learners attending the program in twenty one FAL centers in Sheshamane city. Even though Shashemene city has implemented the IFAE program for the last seven years, no scientific study was conducted on adult learns' perception and challenges of the provision of the program. To this end, the study has addressed the following basic research questions:

1. How do adult learners perceive the relevance of the program in changing of the socio- economic status in the study area?

2. What are the challenges that encounter the IFAE implementation in the study area?

\section{Methods}

\subsection{Sites}

This study was conducted in Shashemene city administration of Oromia regional state extending from $40^{\circ} 28$ to $40^{0} 50$ E longitude and $08^{0} 10$ to $08^{0} 43 \mathrm{~N}$ latitude with an area of $768.88 \mathrm{~km}^{2}$. It is located at $250 \mathrm{~km}$ south of Addis Ababa national capital City at the edge or escarpment of East African Rift Valley (figure 3.1) the location made the area adjacent to high land and low land having the agro ecological zones kolla (tropical), woinadega (subtropical) and Dega (high land) 
Figure 3.1: Location of study area.

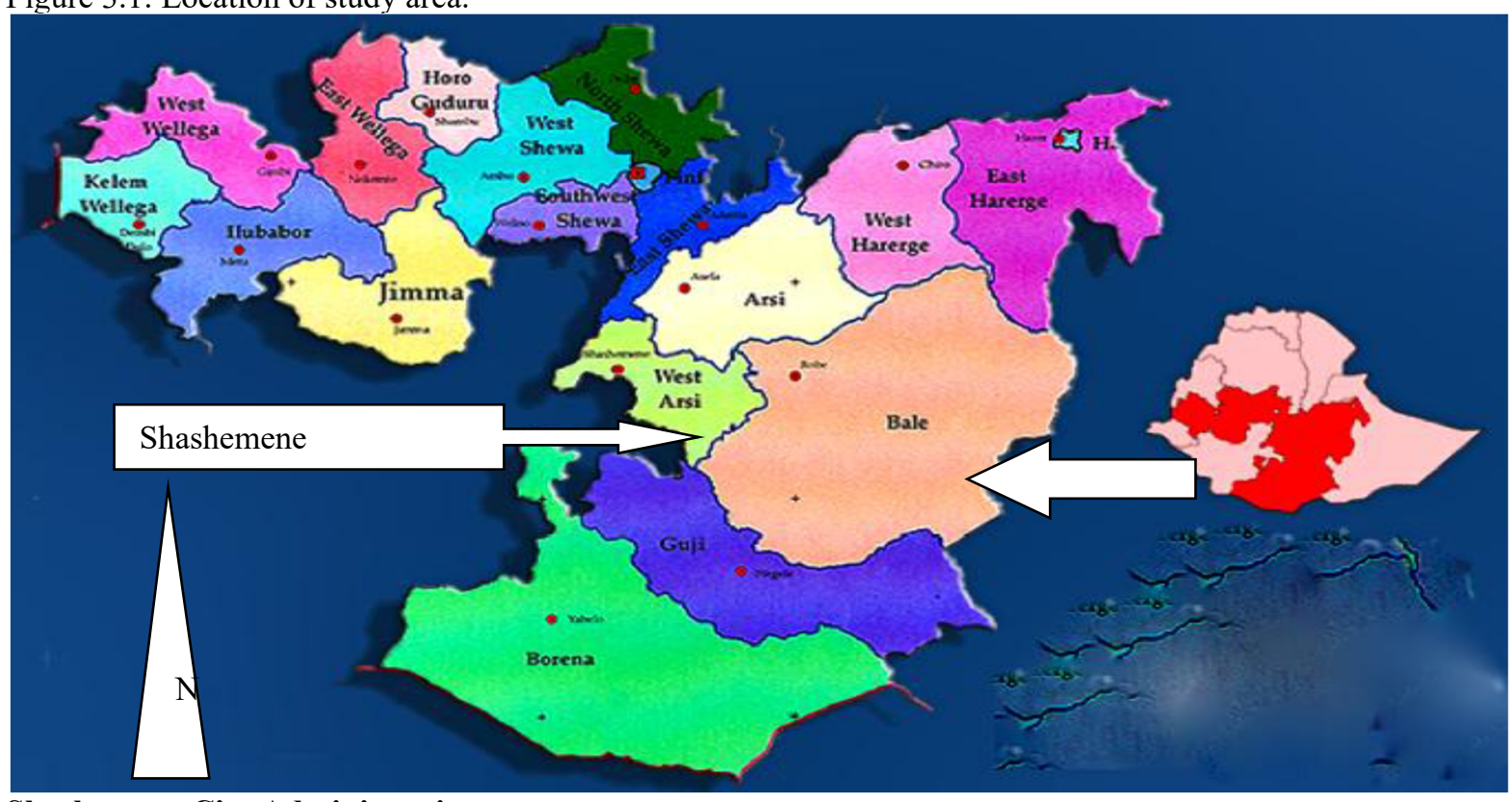

\section{Shashemene City Administration}

According to the 2007 report of CSA, the City has a total of 290,000 populations who are living in 8 sub City (pcc, 2007). According to Shashemene City statistical center the City is the center of business and also consists different service giving institutions like Banks, Insurances, Colleges, Schools and nationally communicating roads or gate ways by which Addis Ababa, Wando, Arbaminch, Hawassa and Bale are connecting each other which makes the City center of business.

\subsection{Research design}

According to James and Sally (2001) descriptive survey is a method which was used to explore relationships between variables and allows generalizations across the population. Therefore, it was used in this study because it enables the researcher to obtain accurate information for large numbers of population using a small sample. A survey design was referred because it concerns itself with describing practices to determine the current status of that population with regard to one or more variables. The usefulness of this design was convenient in collecting extensive quantifiable data from a large sample of respondents within a short period of time

\subsection{Research method}

In this study, mixed method (qualitative and quantitative) with parallel convergent design was used to generate and analyze information obtained from diverse groups of respondents. The quantitative method helps the researcher to analyze the quantitative data obtained through the use of a questionnaire with close-ended question items whereas the qualitative method helps to analyze the data obtained through the use of semi-structured interview guide, focus group discussion (FGD) and observation checklist.

\subsection{Data sources}

The data for this study was obtained from both primary and secondary. The primary data for this study was collected from IFAL learners, sub-city chair persons, facilitators, IFAE coordinators, women affairs experts, youth and sport experts, health extension workers, school supervisors, school directors and Shashemene city education office experts using questionnaire, FGD and interview. Whereas, secondary data was obtained from documents. These documents include: minutes, centers, school records on IFAL implementation, policy and strategy documents related to IFAL.

\subsection{Sample and Sampling techniques}

Out of the available 21 IFAE centers of the sub-city, the following ten IFAE centers were included by using simple random sampling technique: Burke Gudina first cycle, Biruh idget fana private school first cycle, Melka Essa first cycle, Arada kebele, Biherawi first cycle, Lucy private school first cycle, Salam private school first cycle, Lucy 04 private school first cycle, Birbirsa kerata first cycle and katolic 01private school first cycle. With regards to sample the population under the study, out of 400 adult learners, 120 were selected by using the formula of Cohen et.al (2013). Therefore, the sample size for adult learners was calculated as follows: $400 \times 30 \%$ So that, $(=120)$. However, health extensions workers, supervisors, school Principals, City education experts, Sub- city chair person, 
women affairs experts and youth and sport experts were selected in available sampling techniques because these respondents were the only option to be included in the study. So that 120 adult learners, 4 health extensions workers, 10 facilitators, 4 supervisors, 5 school Principals, 2 City education experts, 5 Sub- city chair person, 2 women affairs experts and 2 youth and sport experts, 2 Small and medium enterprise experts were respondents of this study. The sums of these respondents give rise to 156 subjects. Generally, 156 respondents were included in this study. In short target population, sample and the sampling techniques employed in the study were:-

\subsection{Data collection instruments}

In this study, questionnaire; unstructured interview, focus group discussion and observation check list. The questionnaires were prepared in English language then translated to Afan Oromo to minimize the language barrier and used to collect data from groups of respondents IFAE learners and facilitators. According to Best, (2004), questionnaire was widely used in educational research to obtain information about certain conditions and practices, and inquire into opinions and attitudes of individuals or groups. On the other hands, unstructured interview was employed to collect factual and detail information from Shashemane City education office IFAL experts, City education supervisor, health extension workers, Sub City chair person, Women affairs Youth and Sport and SME experts. Since the main purpose of interview was to get additional information from responsible bodies, the key content of the questionnaires were included in the interview questions in order to supplement questionnaires responses. In addition, Focus group discussion (FGD) observations were used to triangulate information obtained by using other data collection instruments and watching to an interaction or phenomenon as it takes place respectively.

\subsection{Methods of data analysis.}

In this study the response that was obtained from questionnaire, interview, focus group discussion and observation were organized, summarized and analyzed qualitatively and quantitatively. To analyze the quantitative data for example, the data gathered through close ended questions was first presented in the tables and statistically analyzed. On the other hand, the collected data was coded and analyzed using SPSS-20. Quantitative data were analyzed using percentage, frequency, mean and independent t-test. Qualitative data were analyzed systematically using narrative and quotation approach to substantiate quantitative analysis.

\section{Result}

\subsection{Socio demographic characteristics of the respondents}

The major demographic characteristics of respondents include sex, age, marital status, educational level and their work of experiences.

Table 4.1 Socio demographic characteristics of the respondents

\begin{tabular}{|c|c|c|c|c|c|c|}
\hline \multirow[t]{2}{*}{ R.No. } & \multirow{2}{*}{\multicolumn{2}{|c|}{ Variables }} & \multicolumn{2}{|c|}{ IFAL Learners } & \multicolumn{2}{|c|}{ IFAL Facilitators } \\
\hline & & & No & $\%$ & No & $\%$ \\
\hline \multirow[t]{2}{*}{1} & \multirow[t]{2}{*}{ Sex } & Male & 24 & 21.8 & 7 & 70 \\
\hline & & Female & 86 & 78.2 & 3 & 30 \\
\hline \multirow[t]{4}{*}{2} & \multirow[t]{4}{*}{ Age } & Below 20 & 42 & 38.2 & 3 & 30 \\
\hline & & $21-30$ & 48 & 43.6 & 6 & 60 \\
\hline & & $31-40$ & 16 & 14.5 & 1 & 10 \\
\hline & & Above 40 & 4 & 3.6 & & \\
\hline \multirow[t]{4}{*}{3} & \multirow[t]{4}{*}{ Marital status } & Single & 48 & 43.6 & 6 & 60 \\
\hline & & Married & 58 & 52.7 & 4 & 40 \\
\hline & & Divorced & 4 & 3.6 & & \\
\hline & & Widow & & & & \\
\hline \multirow[t]{3}{*}{4} & \multirow[t]{3}{*}{ Education level } & Level one & & & & \\
\hline & & Level two & 110 & 100 & & \\
\hline & & $10-12$ & & & 10 & 100 \\
\hline \multirow[t]{3}{*}{5} & \multirow[t]{3}{*}{ Work experience } & $1-5$ & & & 10 & 100 \\
\hline & & $6-10$ & & & & \\
\hline & & $11-20$ & & & & \\
\hline \multicolumn{2}{|c|}{ Total Population } & & 110 & & 10 & \\
\hline
\end{tabular}

Source: Field survey, 2018

As indicated in table 1 above, a total of 120 respondents of IFAE learners and facilitators were included in the study. 31 (25.83\%) respondents were males while the remaining $89(74.17 \%)$ are females. The researcher sampled proportion of respondents by sex proportion of their enrollment.

With regards to age of respondents, the IFAL facilitators and learners, $45(37.5 \%)$ were in the age group of 
below 20 years. The others 54 (45\%) respondents were between the age group of 21-30 years. Thus the majority of the respondents were in this age group. 17 (14.17\%) respondents were between the age group of 31-40 years. and the rest very few $4(3.33 \%)$ respondents were in the age group of above 40 years.

Regarding to marital status of the respondents the majorities $6(60 \%)$ of IFAL facilitators and $48(43.6 \%)$ of IFAE learners were single, while $4(40 \%)$ of IFAL facilitators, $58(52.7 \%)$ of IFAE learners were married. Whereas $4(3.6 \%)$ IFAL learners were divorced.

With regards to educational level of the same table, $10(100 \%)$ were grade $10-12$ complete. All IFAE learners $110(100 \%)$ were level two and they were able to read and write. Regarding item 5, the experience of facilitators, most of them had a work experience ranging between one and five years.

Regarding to work experiences of the Sub City chair person, City education supervisors, health extension workers, School Principals, IFAL experts from Women affairs, City education experts, SME experts and IFAL experts from Youth and sport indicate that all the $22(91.67 \%)$ of them are first degree holders and The remaining $2(8.33 \%)$ health extension workers had diploma. The majority of the them are 6 and above years of service experience

4.2. Issue related to the view of adult learner on IFAL contribution to their socio economic status. Table 4.2: IFAL learners and Facilitators response based on the view of adult learner on IFAL contribution to their socio-economic status.

\begin{tabular}{|c|c|c|c|c|c|c|c|}
\hline \multicolumn{8}{|c|}{ Independent $\mathrm{t}$ test analysis } \\
\hline \multicolumn{2}{|c|}{ Group of respondents } & \multirow{2}{*}{$\begin{array}{l}\mathrm{N} \\
110\end{array}$} & \multirow{2}{*}{$\begin{array}{l}\text { Mean } \\
3.7545\end{array}$} & \multirow{2}{*}{$\begin{array}{l}\text { Std. } \\
\text { Deviation } \\
.97854\end{array}$} & \multirow{3}{*}{$\begin{array}{c}\mathrm{T} \\
-1.739\end{array}$} & \multirow{3}{*}{$\begin{array}{l}\text { Df } \\
118\end{array}$} & \multirow{3}{*}{$\begin{array}{l}\text { Sig. } \\
.320\end{array}$} \\
\hline \multirow{2}{*}{$\begin{array}{l}\text { 1. The adult learners perceived } \\
\text { the functional adult literacy } \\
\text { program positively. }\end{array}$} & $\begin{array}{l}\text { IFAE } \\
\text { learners }\end{array}$ & & & & & & \\
\hline & $\begin{array}{l}\text { IFAE } \\
\text { facilitators }\end{array}$ & 10 & 4.3000 & .48305 & & & \\
\hline \multirow{2}{*}{$\begin{array}{l}\text { 2. The adult learners are satisfied } \\
\text { with the teaching-learning } \\
\text { process in the IFAL center. }\end{array}$} & $\begin{array}{l}\text { IFAE } \\
\text { learners }\end{array}$ & 110 & 3.7909 & 1.05878 & \multirow[t]{2}{*}{.554} & \multirow[t]{2}{*}{118} & \multirow[t]{2}{*}{.701} \\
\hline & $\begin{array}{l}\text { IFAE } \\
\text { facilitators }\end{array}$ & 10 & 3.6000 & .84327 & & & \\
\hline \multirow{2}{*}{$\begin{array}{l}\text { 3. The adult learners attending } \\
\text { the IFAL program based on their } \\
\text { own interest. }\end{array}$} & $\begin{array}{l}\text { IFAE } \\
\text { learners }\end{array}$ & 110 & 3.8545 & 1.00308 & \multirow[t]{2}{*}{1.376} & \multirow[t]{2}{*}{118} & \multirow[t]{2}{*}{.421} \\
\hline & $\begin{array}{l}\text { IFAE } \\
\text { facilitators }\end{array}$ & 10 & 3.4000 & .96609 & & & \\
\hline \multirow[t]{2}{*}{$\begin{array}{l}\text { 4. Adult learners are confidential } \\
\text { participating on their education. }\end{array}$} & $\begin{array}{l}\text { IFAE } \\
\text { learners }\end{array}$ & 110 & 4.0000 & .90867 & \multirow[t]{2}{*}{.996} & \multirow[t]{2}{*}{118} & \multirow[t]{2}{*}{.793} \\
\hline & $\begin{array}{l}\text { IFAE } \\
\text { facilitators }\end{array}$ & 10 & 3.7000 & .94868 & & & \\
\hline \multirow{2}{*}{$\begin{array}{l}\text { 5. The adult learners believe that } \\
\text { they are direct beneficiaries of } \\
\text { the IFAL program. }\end{array}$} & $\begin{array}{l}\text { IFAE } \\
\text { learners }\end{array}$ & 110 & 3.9364 & .73294 & \multirow[t]{2}{*}{-1.536} & \multirow[t]{2}{*}{118} & \multirow[t]{2}{*}{.736} \\
\hline & $\begin{array}{l}\text { IFAE } \\
\text { facilitators }\end{array}$ & 10 & 4.3000 & .48305 & & & \\
\hline \multirow{2}{*}{$\begin{array}{l}\text { 6. The adult learners believe that, } \\
\text { the IFAE program is important } \\
\text { for the improvement of the adult } \\
\text { living condition. }\end{array}$} & $\begin{array}{l}\text { IFAE } \\
\text { learners }\end{array}$ & 110 & 3.8818 & .86451 & \multirow[t]{2}{*}{-.431} & \multirow[t]{2}{*}{118} & \multirow[t]{2}{*}{.065} \\
\hline & $\begin{array}{l}\text { IFAE } \\
\text { facilitators }\end{array}$ & 10 & 4.0000 & .00000 & & & \\
\hline \multirow{2}{*}{$\begin{array}{l}\text { 7. The adult learners believe that } \\
\text { facilitators are working as a } \\
\text { change agent for the success of } \\
\text { IFAL program and treat IFAL } \\
\text { learners with respect. }\end{array}$} & $\begin{array}{l}\text { IFAE } \\
\text { learners }\end{array}$ & 110 & 2.3364 & 1.11106 & \multirow[t]{2}{*}{-3.360} & \multirow[t]{2}{*}{118} & \multirow[t]{2}{*}{.001} \\
\hline & $\begin{array}{l}\text { IFAE } \\
\text { facilitators }\end{array}$ & 10 & 3.6000 & 1.42984 & & & \\
\hline
\end{tabular}

Source: Field survey January,2018

$\mathrm{SDA}=1-1.49, \mathrm{DA}=1.50-2.49, \mathrm{UD}=2.50-3.49, \mathrm{~A}=3.50-4.49, \mathrm{SA}=4.50-5.0$

Regarding item no.1 of table 4.2 the computed mean result of the respondents show agree for IFAE learners $(\mathrm{M}=3.75, \mathrm{SD}=.98)$ and Strongly agree for IFAE facilitators $(\mathrm{M}=4.30, \mathrm{SD}=.48)$. This is also confirmed by independent $\mathrm{t}$-test as $(\mathrm{t}=-1.74, \mathrm{P}>0.05, \mathrm{df}=118)$. The conclusion therefore is that there was no significance mean difference between the response of IFAE learners and facilitators with regard to the learners positive perception of IFAE program. To support this idea focus group discussion held with WFGR 07:

"She replied that Truly speaking, my heart's desire was achieved. After IFAL I started to give value for my 
prior knowledge, skills and experience and the potential inside me. I can totally change into resources. IFAE gives me a sense of confidence to see myself again and again. Yes! We all women have the power to change ourselves, our family and our community, though most of us were not aware of this truth. So we perceived IFAL positively "(February 18,2018).

Regarding item no. 2 of table 4.2 the computed mean result of the respondents show agree for IFAL learners $(\mathrm{M}=3.79, \mathrm{SD}=1.05)$ and agree for IFAE facilitators $(\mathrm{M}=3.6, \mathrm{SD}=.84)$. This is also confirmed by independent $\mathrm{t}$-test as $(\mathrm{t}=.55, \mathrm{P}>0.05, \mathrm{df}=118)$. The conclusion therefore is that there was no significance mean difference between the response of IFAE learners and facilitators. This confirmed that IFAE learners were satisfied with the teaching-learning process.

Regarding item no. 3 of table 4.2 the computed mean result of the respondents show agree for IFAE learners $(\mathrm{M}=3.85, \mathrm{SD}=1.00)$ and agree for IFAL facilitators $(\mathrm{M}=3.5, \mathrm{SD}=.96)$. This is also confirmed by independent $\mathrm{t}$-test as $(\mathrm{t}=1.37, \mathrm{P}>0.05, \mathrm{df}=118)$. The conclusion therefore is that there was no significance mean difference between the response of IFAE learners and facilitators. This confirmed that IFAL learners were attending the IFAL program based on their own interest.

Regarding item no.4 of table 4.2 the computed mean result of the respondents show agree for IFAE learners $(\mathrm{M}=4.00, \mathrm{SD}=.90)$ and agree for IFAE facilitators $(\mathrm{M}=3.7, \mathrm{SD}=.94)$. This is also confirmed by independent $\mathrm{t}$-test as $(\mathrm{t}=.996, \mathrm{P}>0.05, \mathrm{df}=118)$. The conclusion therefore is that there was no significance mean difference between the response of IFAE learners and facilitators. This confirmed that IFAE learners were confidential participating on their education.

Regarding item no.5 of table 4.2 the computed mean result of the respondents show agree for IFAE learners $(M=3.93, S D=.73)$ and agree for IFAE facilitators $(M=4.3, S D=.48)$. This is also confirmed by independent t-test as $(\mathrm{t}=-1.53, \mathrm{P}>0.05, \mathrm{df}=118)$. The conclusion therefore is that there was no significance mean difference between the response of IFAE learners and facilitators. This affirmed that IFAE learners were direct beneficiaries of the program.

Regarding item no.6 of table 4.2 the computed mean result of the respondents show agree for IFAE learners $(\mathrm{M}=3.88, \mathrm{SD}=.86)$ and agree for IFAE facilitators $(\mathrm{M}=4.00, \mathrm{SD}=.00)$. This is also confirmed by independent $\mathrm{t}$-test as $(\mathrm{t}=-.431, \mathrm{P}>0.05, \mathrm{df}=118)$. The conclusion therefore is that there was no significance difference between the response of IFAE learners and facilitators. This affirmed that IFAE learners were believed that the program was important for the improvement of their living condition.

Regarding item no.7 of table 4.2 the computed mean result of the respondents show disagree for IFAE learners $(\mathrm{M}=2.33, \mathrm{SD}=1.11)$ and agree for IFAE facilitators $(\mathrm{M}=3.6, \mathrm{SD}=1.42)$. This is also confirmed by independent $\mathrm{t}$-test as $(\mathrm{t}=-3.36, \mathrm{P}<0.05, \mathrm{df}=118)$. The conclusion therefore is that there was significance mean difference between the response of IFAE learners and facilitators. This affirmed that The adult learners believe that facilitators were not working as a change agent for the success of IFAE program and treat IFAE learners with respect. To support this idea interview held with IFAEEX 01:

" He replied that the major problem that we face in IFAL program is lack of qualified facilitators. This because the facilitators are those who have completed their secondary education and they don 't get any training or workshop before they start the actual teaching in the IFAE program, so when they begin to facilitate the IFAE learners class they are not able to facilitate the adult learners class. Moreover they didn 't know how to handle or treat them with respect and teach in order to meet the learning needs of the IFAL learners."(February 18,2018).

In relation to this Lieb (1991) states that facilitators should establish a friendly and open atmosphere, which will encourage the learners to learn and participate in the classes regularly, which helps to set a feeling or tone for the lesson.

4.3 Issue related to the major challenges that encounter the practices of IFAL

Table 4.3 IFAL learners and Facilitators response based on the major challenges that encounter the practices of IFAL.

\begin{tabular}{|c|c|c|c|c|c|c|c|}
\hline Variables & Resp. & $\mathrm{N}$ & $\mathrm{H}$ & $\mathrm{M}$ & $\mathrm{L}$ & Mean & SD \\
\hline \multirow{2}{*}{$\begin{array}{l}\text { 1. Lack of trained } \\
\text { facilitators and expertise } \\
\text { on andragogy. }\end{array}$} & $\mathrm{L}$ & 110 & $100(90.9 \%)$ & $6(5.5 \%)$ & $4(3.6 \%)$ & \multirow[t]{2}{*}{4.7250} & \multirow[t]{2}{*}{.79876} \\
\hline & $\mathrm{F}$ & 10 & $7(70 \%)$ & $2(20 \%)$ & $1(10 \%)$ & & \\
\hline \multirow{2}{*}{$\begin{array}{l}\text { 2. Lack of awareness of } \\
\text { community. }\end{array}$} & $\mathrm{L}$ & 110 & $85(77.3 \%)$ & $15(13.6 \%)$ & $10(9.1 \%)$ & \multirow[t]{2}{*}{4.4333} & \multirow[t]{2}{*}{1.06695} \\
\hline & $\mathrm{F}$ & 10 & $7(70 \%)$ & $20(20 \%)$ & $1(10 \%)$ & & \\
\hline \multirow{2}{*}{$\begin{array}{l}\text { 3. Lack of financial } \\
\text { support for those engage } \\
\text { in the program. }\end{array}$} & $\mathrm{L}$ & 110 & $62(56.4 \%)$ & $25(22.7 \%)$ & $23(20.9 \%)$ & \multirow[t]{2}{*}{3.9083} & \multirow[t]{2}{*}{1.30928} \\
\hline & $\mathrm{F}$ & 10 & $6(60 \%)$ & $2(20 \%)$ & $2(20 \%)$ & & \\
\hline
\end{tabular}




\begin{tabular}{|c|c|c|c|c|c|c|c|}
\hline Variables & Resp. & $\mathrm{N}$ & $\mathrm{H}$ & $\mathrm{M}$ & $\mathrm{L}$ & Mean & SD \\
\hline \multirow{2}{*}{$\begin{array}{l}\text { 4. Lack of continuous } \\
\text { training to facilitators and } \\
\text { experts. }\end{array}$} & $\mathrm{L}$ & 110 & $76(69.1 \%)$ & $22(20 \%)$ & $12(10.9 \%)$ & \multirow[t]{2}{*}{4.2333} & \multirow[t]{2}{*}{1.17918} \\
\hline & $\mathrm{F}$ & 10 & $6(60 \%)$ & $2(20 \%)$ & $2(20 \%)$ & & \\
\hline \multirow{2}{*}{$\begin{array}{l}\text { 5. Lack of continuous } \\
\text { supervision from city } \\
\text { education office. }\end{array}$} & $\mathrm{L}$ & 110 & $68(61.8 \%)$ & $22(20 \%)$ & $20(18.2 \% 0$ & \multirow[t]{2}{*}{4.0333} & \multirow[t]{2}{*}{1.28294} \\
\hline & $\mathrm{F}$ & 10 & $6(60 \%)$ & $2(20 \%)$ & $2(20 \%)$ & & \\
\hline \multirow{2}{*}{$\begin{array}{l}\text { 6. Lack of teaching } \\
\text { materials (pen, pencil, } \\
\text { exercise book etc) and } \\
\text { demand drive guideline }\end{array}$} & $\mathrm{L}$ & 110 & $73(66.4 \%)$ & $20(18.2 \%)$ & $17(15.5 \%)$ & \multirow[t]{2}{*}{4.1750} & \multirow[t]{2}{*}{1.21380} \\
\hline & $\mathrm{F}$ & 10 & $7(70 \%)$ & $2(20 \%)$ & $1(10 \%)$ & & \\
\hline \multirow{2}{*}{$\begin{array}{l}\text { 7. Lack of structure } \\
\text { system with role and } \\
\text { responsibilities to run the } \\
\text { program. }\end{array}$} & $\mathrm{L}$ & 110 & $73(66.4 \%)$ & $18(16.4 \%)$ & $19(17.3 \%)$ & \multirow[t]{2}{*}{4.1417} & \multirow[t]{2}{*}{1.25889} \\
\hline & $\mathrm{F}$ & 10 & $7(70 \%)$ & $2(20 \%)$ & $1(10 \%)$ & & \\
\hline \multirow{2}{*}{$\begin{array}{l}\text { 8. Lack of the political } \\
\text { commitment among } \\
\text { leaders to sustain the } \\
\text { literacy campaign. }\end{array}$} & $\mathrm{L}$ & 110 & $74(67.3 \%)$ & $26(23.6 \%)$ & $10(9.1 \%)$ & \multirow[t]{2}{*}{4.2667} & \multirow[t]{2}{*}{1.12072} \\
\hline & $\mathrm{F}$ & 10 & $8(80 \%)$ & $1(10 \%)$ & $1(10 \%)$ & & \\
\hline \multirow{2}{*}{$\begin{array}{l}\text { 9. Lack of integrated } \\
\text { effort of education office } \\
\text { with other Sectors. }\end{array}$} & $\mathrm{L}$ & 110 & $70(63.6 \%)$ & $30(27.3 \%)$ & $10(9.1 \%)$ & \multirow[t]{2}{*}{4.1833} & \multirow[t]{2}{*}{1.13747} \\
\hline & $\mathrm{F}$ & 10 & $6(60 \%)$ & $2(20 \%)$ & $2(20 \%)$ & & \\
\hline \multirow{2}{*}{$\begin{array}{l}\text { 10. Lack of motivation of } \\
\text { facilitators. }\end{array}$} & $\mathrm{L}$ & 110 & $75(68.2 \%)$ & $25(22.7 \%)$ & $10(9.1 \%)$ & \multirow[t]{2}{*}{4.2333} & \multirow[t]{2}{*}{1.12072} \\
\hline & $\mathrm{F}$ & 10 & $5(50 \%)$ & $3(30 \%)$ & $2(20 \%)$ & & \\
\hline \multirow{2}{*}{$\begin{array}{l}\text { 11. Lack of Permanent } \\
\text { budget, inadequate } \\
\text { facility and learning } \\
\text { environment. }\end{array}$} & $\mathrm{L}$ & 110 & $70(63.6 \%)$ & $32(29.1 \%)$ & $8(7.3 \%)$ & \multirow[t]{2}{*}{4.1833} & \multirow[t]{2}{*}{1.10752} \\
\hline & $\mathrm{F}$ & 10 & $6(60 \%)$ & $2(20 \%)$ & $2(20 \%)$ & & \\
\hline \multirow{2}{*}{$\begin{array}{l}\text { 12. Lack of coordination } \\
\text { among } \\
\text { stakeholders(WEO,REB, } \\
\text { MOE) }\end{array}$} & $\mathrm{L}$ & 110 & $78(70.9 \%)$ & $22(20 \%)$ & $10(9.1 \%)$ & \multirow[t]{2}{*}{4.3167} & \multirow[t]{2}{*}{1.10752} \\
\hline & $\mathrm{F}$ & 10 & $7(70 \%)$ & $2(20 \%)$ & $1(10 \%)$ & & \\
\hline \multirow{2}{*}{$\begin{array}{l}\text { 13. Lack of connecting } \\
\text { the program with primary } \\
\text { education program in } \\
\text { curricula. }\end{array}$} & $\mathrm{L}$ & 110 & $75(68.2 \%)$ & $20(18.2 \%)$ & $15(13.6 \%)$ & \multirow[t]{2}{*}{4.2417} & \multirow[t]{2}{*}{1.18105} \\
\hline & $\mathrm{F}$ & 10 & $8(80 \%)$ & $1(10 \%)$ & $1(10 \%)$ & & \\
\hline \multirow{2}{*}{$\begin{array}{l}\text { 14. Low payment of } \\
\text { facilitators } \\
\text { coordinators. }\end{array}$} & $\mathrm{L}$ & 110 & $77(70 \%)$ & $30(27.3 \%)$ & $3(2.7 \%)$ & \multirow[t]{2}{*}{4.3750} & \multirow[t]{2}{*}{1.00472} \\
\hline & $\mathrm{F}$ & 10 & $8(80 \%)$ & $1(10 \%)$ & $1(10 \%)$ & & \\
\hline Average grand Mean & & & & & & 4.0 & \\
\hline
\end{tabular}

Field survey: January, 2018

NB: Analysis interval of mean score: $1.0--2.5=$ Low, $2.51-3.5=$ Medium, 3.51--5.0= High , F=Facilitators \& $\mathbf{L}=$ Learner.

To analyze this data the researchers merged Very high and high = "High", Low and Very Low =" Low"

Regarding items 1-14 of Table 4.3, most of the respondents (IFAE learner and facilitators) confirmed that lack of trained facilitators and expertise, lack of community awareness, lack of financial support, lack of continuous supervision, low quality of teaching materials, lack of structures system, lack of interest and motivation of facilitators, low political commitments among political leaders to sustain the IFAE program, lack of integrated effort of education office with other Sectors, lack of Permanent budget, inadequate facility and learning environment, lack of coordination among stakeholders(WEO,REB,MOE), lack of connecting the program with primary education program in curricula and low payment of facilitators and coordinators were the major challenges. The average grand combined mean of respondents was $\mathbf{4 . 0}$ which indicated that problem for the above listed items were high.

Likewise, during focus group discussion most of participants confirmed that government in Ethiopia has political will but not committed to implement IFAE program. Moreover, there is no consistent discussion and leadership commitment towards mass IFAE in the Shashemene City Administration. For that reason, we suggested that IFAE program required the commitment of the regional government in strategic planning, financing, and 
delivering and working with range of partners. Similarly, local research conducted by Mohammed (2013) concluded that, lack of incentive and adequate training of facilitators, low commitment and motivation of facilitators, lack of adequate budget and facilities affect the implementation of IFAE program in Eastern Hararghe.

Furthermore, during the series of discussions with adult education experts, facilitators and supervisors it was disclosed that the government made many efforts to build the technical capacity of IFAE staff, developed guidelines, directives, and training materials. However, the impact is not desirable as participants of focus group discussion and interviewees explained it.

It was found out that the following major challenges and constraints were negatively affecting the existing Integrated Functional Adult Education practices in Shashemene City Administration:

1) Adult education boards do not operate effectively at all levels. This makes implementation, coordination, linkage between program providers more difficult.

2) Absences of trained and committed experts to manage and coordinate the programs were made the expected technical support more complicated.

3 ) Low and inconsistent budget allocation, poor capacity of facilitators and shortage of infrastructure at the training centers such as learning materials and other logistics provisions were affecting the practice of IFAE implementation program.

4) Low and incompetent facilitators' with inefficient andragogical, monitoring and evaluation skills in most of IFAE centers. This makes the teaching learning process traditional and many of participants could not be assessed effectively.

5) Low and inconsistent salary of facilitators and lack of continuous professional development program that forced the facilitators for high turnover.

6) Poor political commitment of leaders and misunderstanding on the program at various level and absence of well-organized and independent managing structure for the program.

\subsubsection{Suggested possible solutions to the above listed problems:-}

As solution to the above stated major Challenges of the integrated functional adult education program, IFAE facilitators and Coordinators, IFAL learners, Shashemene City Education supervisors, IFAL center school Principals, health extension workers, IFAE experts from Women affairs, IFAE experts from Youth and sport and SME experts suggested the following points.

To teach the community continuously about the advantages of to be literate and to explain in detail possible benefits that could be gained in the future and the Government, NGOs and civil societies should work on awareness creation through mass media and printed material hierarchically and consistently.

To accomplish the IFAE plan prepared each year successfully and to reduce the illiteracy adult's rate and to raise the commitment of IFAL facilitators in the City, training and adequate budget should be allocated for the practice of IFAE implementation program.

To improve the guide lines, learner's books and to keep the quality of the books moreover to work together in all stakeholders to improve integrated functional adult education program, all the stakeholders integrated give serious attention for the program, establishing quality and relevant IFAL system.

\section{Discussion}

The findings showed that the female participation in IFAL program is by far more than that of the males. This implies that the participation of women's in the program is at better condition (level). This confirms that the case in focusing ESDP V adult and non-formal education program resources on increasing female participation and completion rates seem to be improved at Shashemene City Administration. Of the target 19.4 million illiterate adults targeted by the program, 12.4 million (64\%) are female (MoE, 2015).

The result revealed that most of adult learners were found under productive age range between 15 and 60 . The qualifications of all facilitators fit with the IFAL guideline which says they should at least be grade 10 complete. Regarding to Marital status of respondents, the result showed that, respondents have been working and have family responsibility. The result also revealed that, majorities of learners were level two and they were able to read and write. In addition, there was a shortage of more experienced IFAL program facilitators. City is equipped with sufficiently qualified and experienced human resource and these qualification and experience were good to manage the work. In relation to this, to implement IFAL at a large scale, well trained, experienced and qualified personnel are needed to plan, implement, coordinate, supervise, facilitate, monitor and evaluate the program (sandhaas, 2008).

\section{The view of adult learner on IFAL contribution to their socio-economic status}

Concerning the view of adult learner on IFAL contribution to their socio-economic status the majority of the respondents agreed as providing the learners positive perception, positive attitudes towards the program, satisfaction of learners with teaching-learning process in the IFAL center, adult learners have understanding on the advantage (importance) of to be literate, their confidence when participating through IFALP and they are direct 
beneficiaries of IFALP. Beside facilitators not working as change agent for success of IFALP are certain attitudes of adult learners in the study area.

\section{The major challenges that encounter the practices of IFAL}

Regarding the challenges that encountered the current practice of IFAL program implementation the majority of the respondents agreed that there is lack of trained facilitators and expertise, lack of community awareness, lack of financial support, lack of continuous supervision, low quality of teaching materials, lack of structures system, lack of interest and motivation of facilitators, low political commitments among political leaders to sustain the IFAL program, lack of integrated effort of education office with other Sectors, lack of Permanent budget, inadequate facility and learning environment, lack of coordination among stakeholders(WEO,REB,MOE), lack of connecting the program with primary education program in curricula and low payment of facilitators and coordinators were major challenges that encountered in the implementation of IFAE program. With respect to possible ways provided to improve the current practice of IFAE program implementation the majority of the respondents agreed as providing incentives for facilitators and coordinators, supplying sufficient facilities, allocating budget, preparing guide line for coordinated sectors at center, all the stakeholders integrated give serious attention for the program, adequate facilitators training and creating learners awareness were the possible ways to improve the practice of IFAL program implementation.

\subsection{CONCLUSIONS}

Based on the major findings, the following conclusions were drawn. The major objective of the study was to explore the practice, challenges and opportunities of IFAE in Shashemene City Administration.

The practice of integrated functional adult education has been benefited considerable number of adults live in the Shashemene City Administration. Therefore, it providing the learners positive perception, positive attitudes towards the program, satisfaction of learners with teaching-learning process in the IFAL center, adult learners have understanding on the advantage (importance) of to be literate, their confidence when participating through IFALP and they are direct beneficiaries of IFALP. Beside facilitators not working as change agent for success of IFALP are certain attitudes of adult learners in the study area.

However, lack of trained facilitators and expertise, lack of financial support, lack of continuous supervision, low quality of teaching materials, lack of structures system, lack of interest and motivation of facilitators, low political commitments among political leaders to sustain the IFAL program, lack of integrated effort of education office with other Sectors, lack of Permanent budget, inadequate facility and learning environment, lack of coordination among stakeholders(WEO,REB,MOE), lack of connecting the program with primary education program in curricula and low payment of facilitators and coordinators and low awareness of community affect the practice of IFAL program implementation

\subsection{RECOMMENDATIONS}

Based on the preceding findings and conclusions the following recommendations were forwarded:

This study revealed that considerable number of facilitators and experts were not well trained on adult education theoretical and practical matters that help us to appropriately manage, deliver and assess IFAE program. Hence, it is recommended that regional government shall develop appropriate and demand driven instructional materials and mode of delivery, afford infrastructures, improve training and employment condition and professionalization of adult educators, design measurement, monitoring and evaluation mechanism at all stages; input, process and out come to ensure quality IFAE in the region.

Shashemene City Administration education office is recommended to organize short-term training for facilitators of integrated functional adult education so that they would improve their facilitation, knowledge and skills.

Shashemene City Administration IFAE supervisors shall be recommended that, they provide timely feedback for facilitators concerning the strengths and weaknesses they observed in the practice of IFAL in the centers.

City education officers, sub city adult coordinators, Community, private sectors and NGOs shall assist by supplying the adequate teaching-learning materials such as textbooks, exercise books and others supplementary materials.

For the effective IFAL learners perception the relevance of the program in changing of the socio-economic status, Shashemene City Education office, IFAL supervisors, School principals, Sub City IFAE coordinator and Integrated sectors shall play their own roles properly by changing the attitude of adult learners.

The study shows that inadequate of skilled human resource, inadequate of trained facilitators and expertise, inadequate of financial support, lack of continuous supervision, low quality of teaching materials, lack of structures system, lack of interest and motivation of facilitators, low commitments among political leaders to sustain the IFAL program, lack of integrated effort of education office with other Sectors, lack of Permanent budget, inadequate facility and learning environment, lack of coordination among stakeholders(WEO,REB,MOE), lack of 
connecting the program with primary education program in curricula and low payment of facilitators and coordinators, low awareness of community were identified as major constraints of IFAE in the City. In order to reduce these problems City's cabinets should considerably discuss on issues of IFAE as one of the international and national agendas with concerned bodies to improve IFAE organization and management in allocating adequate budget, motivating practitioners through material or moral rewards, and they should devote their time and able to use favorable conditions like meetings, conferences and workshops to aware communities importance of IFAL. Finally, to identify the gap area of the program and to inform implementers and concerned stakeholders; there shall be research and consultancy activities with concerned academic institutions in order to made evidence based decision.

\author{
Abbreviation \\ IFALP: Integrated functional adult literacy programme, WEO: Woreda Education office, REB: regional education \\ Bureau \\ Declaration
}

\title{
Authors' contributions
}

Birhanu Jima: Corresponding authors from Department of Adult Education and Community Development, college of Education and Behavioral Studies of Madda Walabu University. He published three journals. He worked a lot so as to prepare and manuscript. He worked a lot from data collection up to analysis, conclusion and recommendation.

Ayele Kumsa: is contributed a lot for this manuscript. He guide the way to re arranged manuscript. He edited the manuscript before submission. Furthermore, he played a great role in finding recent reputable journal publishers.

\section{Competing interests}

The author declare that they have no competing interests.

\section{Availability of data and materials}

The data supporting the conclusions of the article are included within the article. Any queries regarding these data may be directed to the corresponding author.

\section{Consent for publication}

Author have agreed to submit it in its current form for consideration for publication in the journal.

Ethics approval and Consent to participate

Not applicable, no tests

\section{Funding}

This work is not supported by any organization. Finally, this research did not receive any specific grant from funding agencies in the public, commercial, or not-for-profit sectors. It is prepared only for academic competition.

\section{Acknowledgment}

The authors are grateful for the valuable guidance from two anonymous reviewers. The author is also thankful to Shashemene City Administration all adult education practitioners' who have supported and/or inspired this work through the various support.

\section{Refrences}

(1) Adewale, L. (2003). Comprehensive country review on adult learning. Commissioned by the UNESCO Institute of Education in Nigeria: University of Lagos, Akoka.

(2) Aggarwal, J. C. 2002. Recent Developments and Trends in Education.New Delhi. Shipra Publications

(3) Best. (2004). Research in Education.New Jersey Orentice Hall.

(4) Cohen Louis, M. L. (2013). Research Methodology in Education.Sixth edition. New York.

(5) James, O. and Sally, A. (2001). A study in the problems of Harnessing community and Education in Tanzania. Dere Salaam:Makerere University.

(6) Kagoda, P.K. (1999). Management and Training for civil Society Organisations.

(7) Tripartite Training Programme (DENIVA, URDT, ACFODE). Kampala:

(8) Lieb, S. (1991). Principles of adult learning [Electronic Version]. Retrieved June, 2014fromhttp://honolulu.hawaii.edu/intranet/committees/FacDevCom/guidebk/teachtip/adults-2.htm.

(9) Lind, A.(2008).Literacy for All:Making a Difference.Paris: UNESCO.

(10) Makgwana Rampedi, (2004). Adult Education and Poverty Alleviation: A Constant flow of tears? Retrieved 
12/6/2005 from http://www.aepr.co.bw/aepr/html/abstracts

(11) $\mathrm{MoE}$ (Ministry of Education). (2008)a.National report on the development and state of the art of adult learning and education, Addis Ababa, Ethiopia. Addis Ababa: Ethiopia.

(12) Ministry of Education (MoE.) 2009. National Ault Education Strategy. Addis Ababa: Ethiopia

(13) MoE. (2011). Interated functional adult literacy curriculum framework. Addis Ababa, Ethiopia.

(14) MoE. (2015). Education sector Development Program V (ESDP V) 2008-2012 E.C. Addis Ababa.

(15) UNESCO. (2005).Foundation of Adult Education In Africa: Africa Perspectives on Adult Learning, UNESCO Institute for Education. Hamburg, Germany.

(16)_ 2015a.Narrowing the Gender Gap: Empowering Women through Literacy Programs, Case studies from the UNESCO Effective Literacy and Numeracy Practices Database(Lit Base) Institute for Lifelong Learning.

(17) 2015b.Education For All: 2000-2015: Achievemnts and Challenges, EFA Global Monitoring Report, France.

(18) . 2015c.Communities in Action: Lifelong Learning for Sustainable Development, UNESCO Institute for Lifelong: Hamburg, Germany.

(19) _ 2015d.Transforming Our World: Literacy for Sustainable Development, UNESCO Institute for lifelong Learning-UIL. 2015. Hamburg, Germany.\#

(20)_ 2015e.Education for All 2015 National Review Report: Ethiopia.Report prepared for the World Education Forum, Incheon, Republic of Korea.

(21) 2016a.Learning knowledge and skills for agriculture to improve rural livelihoods, France.

(22) 2016b.Education for People and planet: Creating sustainable futures for all. Global education monitoring report, France. 